\title{
UPAYA MENINGKATKAN KEMAMPUAN MENULIS TEKS DESKRIPTIF MENGGUNAKAN MEDIA VISUAL OTENTIK UNTUK SISWA KELAS VII/ 1 SMP N 4 MATARAM
}

\author{
Hj. ANDI MASANI \\ SMP N 4 Mataram,Kec Cakranegara, Mataram \\ e-mail: andimasani15@gmail.com
}

\begin{abstract}
ABSTRAK
Menulis bagi sebagian dari para siswa adalah merupakan sesuatu yang unik,dan kebiasaan yang bisa dilakukan berulang ulang, Oleh karena itu siswa memiliki kesempatan untuk merevisi tulisannya ketika terjadi kesalahan. Meskipun demikian, menulis teks deskriptif berbahasa Inggris tidak hanya sekedar merangkai kata, frase, atau kalimat. Makalah ini menyajikan hasil penelitian tindakan kelas yang bertujuan meningkatkan kompetensi siswauntuk menulis teks deskriptif berb ahasa Inggris melalui media visual otentik. Subyek penelitian adalah 32 siswa kelas VII/1 SMP N 4 Mataram semester 1 tahun pelajaran 2019/2020. Indikator keberhasilan penelitian ini adalah jika minimal terdapat 20 dari 32 siswa $(62,5 \%)$ bisa menulis teks deskriptif berbahasa Inggris dengan lebih bervariasi. Penelitian ini dilaksanakan dalam 2 siklus selama 4 pertemuan. Pada tindakan pertama, siswa mendeskripsikan orang tertentu. Pada tindakan ke dua, siswa mendeskripsikan benda dan tempat tertentu. Penelitian kualitatif dengan metode analisa data berupa triangulasi sumber data menunjukkan hasil bahwa ada peningkatan jumlah siswa yang telah mencapai KKM. Dari keadaan semula hanya 5 dari 32 siswa (15,63\%), setelah diadakan tindakan siklus pertama dan ke dua, ada peningkatan jumlah siswamasing-masing $15(46,88 \%)$ dan 26 siswa (81\%) mencapai KKM. Simpulannya, pembelajaran melalui media visual otentik dapat meningkatkan kompetensi siswa kelas VII/1 SMP Negeri 4 Mataram semester 1 tahun pelajaran 2019/2020 untuk menulis teks deskriptif berbahasa Inggris dengan lebih bervariasi.
\end{abstract}

Kata kunci : Menulis teks deskriptif berbahasa Inggris, media visual otentik, meningkatkan kemampuan menulis teks deskriptif pada bahasa Inggris

\section{PENDAHULUAN}

Di saat ini literasi begitu penting untuk siswa. Salah satunya literasi Bahasa Inggris,dimana Bahasa inggris merupakan bahasa asing dan saat ini di Indonesia sudah ada dalam kurikulum pengajaran. Yang paling penting untuk tujuan penyerapan dan pengembangan ilmu pengetahuan, teknologi, seni budaya, dan pembinaan hubungan dengan bangsa-bangsa lain yang wajib dipelajari di sekolah lanjutan tingkat pertama( GBPP B. Inggris SLTP 1994).

Dipandang dari segi literasi, tingkat literasi berbahasa Inggris siswa SMP adalah tingkat fungsional untuk tujuan komunikasi survival(Standar Kompetensi Kurikulum 2004). Siswa diharapkan bisa berkomunikasi secara lisan dan tulis untuk menyelesaikan masalah atau memenuhi kebutuhan sehari-hari. Menulis adalah salah satu ketrampilan berbahasa untuk menyampaikan gagasan, pikiran dan perasaannya kepada orang lain. Menulis dianggap ketrampilan berbahasa yang mudah, karena siswabisa segera merevisi tulisannya jika terjadi kesalahan.

Namun demikian, menulis teks deskriptif berbahasa Inggris tidak sekedar merangkai katakata, frasa, atau kalimat. Diperlukan seni dan strategi menulis agar pembaca bisa tertarik. Tulisan dengan tata bahasa yang benar tetapi kurang bervariasi tidak menarik. Bervariasi maksudnya adalah tidak mengulang kata yang sama dalam satu kalimat atau paragraf, dan tidak membuat tulisan yang sama dengan temannya. Media visual yang berbeda antara siswa satu dengan lainnya tidak memungkinkan siswa untuk menyalin/menjiplak pekerjaan temannya.

Selain seni dan strategi, perbedaan yang mencolok antara bahasa Inggris dan bahasa Indonesia mempersulit siswa untuk bisamemproduksi tulisan yang berterima. Sumber kegiatan 
yang seragam merupakan penyebab lain kurangnya kreativitas dan imajinasi siswa dalam menulis. Hanya 6 dari 32 siswa kelas VII/1 $(15,63 \%)$ bisa menulis teks deskriptif dengan bervariasi.

Untuk mengatasi permasalahan tersebut, peneliti mencoba memberikan pembelajaran menggunakan materi otentik berupa gambar (media visual). Media visual otentik yang paling sederhana.yang dekat dengan kehidupan siswa sehari hari. disediakan sendiri oleh siswa sesuai dengan dunia dan kehidupannya bisa membantu siswa memunculkan kreasi, imajinasi, dan gagasan siswa untuk bercerita serta menulis dengan lebih bervariasi.

Pembelajaran menulis teks deskriptif menggunakan media visual otentik diharapkan bisa meningkatkan kemampuan siswa dalam mendeskripsikan orang/benda/tempat tertentu dengan lebih bervariasi.

\section{METODE PENELITIAN}

Penelitian ini dilaksanakan dalam 2 (dua) siklus selama 4 (empat) pertemuan. Pertemuan pertama, siswa mendeskripsikan gambar orang tertentu. Pertemuan ke dua, siswa diberikan penguatan berbagai hal yang masih bermasalah.Pertemuan ke tiga, siswa mendeskripsikan benda/tempat tertentu. Pertemuan terakhir digunakan untuk melakukan refleksi secara keseluruhan.

Setiap siklus ditempuh dalam empat tahap yaitu perencanaan (planning), penerapan tindakan (acting), pengamatan (observing), dan refleksi (reflecting).Setiap tindakan akan dilaksanakan dalam empat tahap, yaitu BKoF, MoT, JCoT, dan ICoT. Berikut penjelasan prosedur penelitian. Subyek penelitian adalah 32 siswa kelas VII/1 semester 1 tahun pelajaran 2019/2020 dengan siswa laki-laki sebanyak 14 siswa dan perempuan 18 siswa.

\section{HASIL DAN PEMBAHASAN}

\section{Deskripsi Kondisi Awal}

Sebelum diadakan tindakan, hanya 5 dari 32 siswa (15,63\%)bisa menulis teks deskriptif dengan bervariasi. Hampir semua siswa menulis kata, frase, dan teks yang sama.Beberapa siswa bahkan tidak menuliskan apa-apa. Perbedaan antara bahasa Indonesia dan bahasa Inggrisserta sumber latihan yang sama,membuat siswa kesulitan menulis teks deskripsi berbahasa Inggris dengan bervariasi.

\section{Siklus I \\ Perencanaan}

Siklus I dilaksanakan di kelasVII/1, hari Selasa, 6 Agustus 2019, jam ke-6dan 7selama 2x40 menit. Sebelumnya, peneliti telah menyiapkan RPP, lembar kegiatan siswa, lembar observasi untuk siswa dan guru, gambar orang, benda,dan binatang tertentu, serta pedoman wawancara.dan lain lain pendukung kegiatan belajar mengajar di kelas .

\section{Hasil Tindakan dan Pengamatan}

Menurut pengamat, rencana pelaksanaan pembelajaran (RPP) sudah disiapkan dengan baik dan lengkap. Guru sudah mengajar sesuai RPP. Guru membuka pembelajaran dengan menyiapkan kondisi siswa dilanjutkan dengan menunjukkan gambar Gedung sekolah dan mengajukan berbagai pertanyaan tentang gambar kepada siswa. Beberapa siswa menjawab dengan salah, yaitu "School ". Lalu salah satu siswa mendeskripsikan My School . Guru membagi siswa dalam kelompok berempat, membaginya satu gambar kepada masing-masing dan meminta 2 perwakilan kelompok untuk mendeskripsikannya. Berikutnya siswa mendeskripsikan gambar benda tertentu secara individu. Pertemuan diakhiri dengan merangkum kegiatan, melakukan refleksi, dan memberikan tugas berlatih tentang unsur kebahasaan dan struktur generik tes deskriptif untuk dibahas pada pertemuan berikutnya. 


\section{Refleksi Siklus I}

Secara umum, sikap siswa selama pembelajaran sudah baik, namun beberapa masih belum bisa bekerja sama dengan baik dan kurang percaya diri. Banyak siswa sering mengganti kata/frase/kalimat yang ditulisnya. Semua siswa telah menyiapkan gambar orang tertentu. Banyak siswa membawa gambar yang sama. Belum semua siswa bisa menuliskan judul yang menggambarkan orang tertentu dengan benar, seperti 'A basket ball Player'. Beberapa siswa masih kurang jelas dalam mengidentifikasi orang yang dideskripsikan, misalnya 'This is A football player. She loves football very much.' berikut:

Kesalahan lain adalah mengulang kata yang sama dalam satu kalimat. Perhatikan paragraf

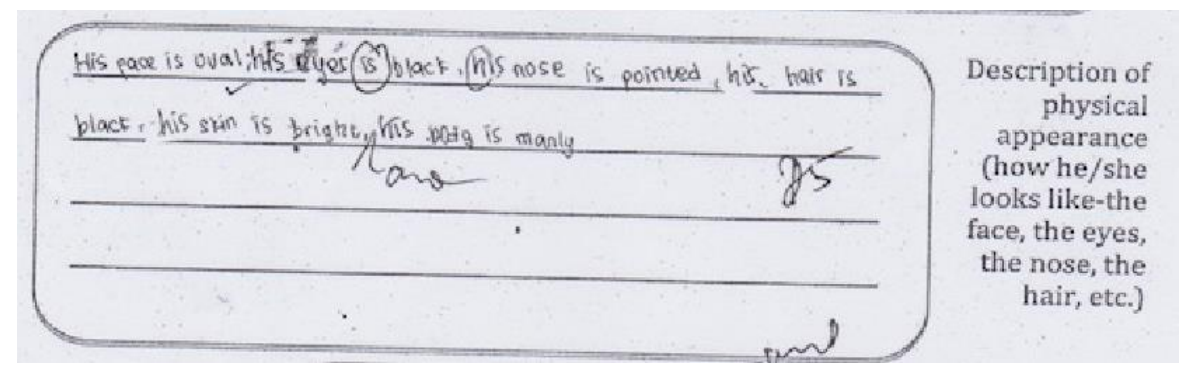

\section{Gambar 5.Cuplikan Tulisan Siswa dalam Mendeskripsikan Fisik Obyek}

Siswa mengulang kata yang sama, yaitu 'football.Masih ada kesalahan dalam penggunaan kata benda .akan tetapi berjalan waktu dan latihan ulang ulang Secara garis besar telah terjadi peningkatan kompetensi siswa dalam menulis teks deskriptif dalam siklus ini, namun hanya 15 siswa $(46,88 \%)$ bisa menulis teks deskriptif dengan lebih bervariasi.

Pada pertemuan ke dua, siswa dipajankan pada pemahaman unsur kebahasaan dan struktur generik teks deskriptif, serta cara membuat frase benda dan kalimat yang lebih bervariasi.

Pembelajaran telah direncanakan dengan baik seperti yang tertuang dalam RPP. Secara umum kegiatan pembelajaran telah dilaksanakan dengan baik, namun masih terdapat beberapa catatan.

\section{Siklus II}

\section{Perencanaan Ulang}

Siklus II tetap dilaksanakan di kelasVII/1, hari Selasa,13 Agustus jam ke-6dan 7 selama 2x40 menit. Peneliti menyiapkan RPP tindakan ke dua, lembar kegiatan siswa, lembar observasi untuk siswa dan guru, serta gambar benda/ orang dan lain lain.

\section{Hasil Tindakan dan Pengamatan}

Menurut pengamat, rencana pelaksanaan pembelajaran sudah disiapkan dengan baik dan lengkap. Guru sudah mengajar sesuai RPP.Guru memulai pembelajaran dengan mempersiapkan kondisi siswa. Setelah itu, guru menunjukkan gambar ' Gedung atau Bangunan' dan mengajukan berbagai pertanyaan. Berikutnya guru mendeskripsikan secara rinci dengan jelas dan meminta siswa untuk menirukannya. Selanjutnya guru memberikan model lain. Kemudian guru membagi siswa dalam kelompok berempat, membaginya satu gambar dan memantau diskusi mereka. 2 perwakilan kelompok mendeskripsikan benda dan tempat tertentu.Siswa mendeskripsikan gambar benda/tempat tertentu secara individu. Guru mengakhiri pembelajaran dengan merangkum materi bersama siswa, melakukan refleksi, dan memberikan tugas. 


\section{Refleksi Siklus II}

Ada kemajuan kegiatan dan hasil belajar siswa maupun guru, meskipun masih ditemukan beberapa kekurangan. Secara umum, sikap siswa selama pembelajaran sudah baik, namun beberapa masih belum percaya diri. Masih banyak siswa yang membawa gambar yang sama.

Masih terdapat siswa yang menuliskan frase benda terbalik seperti yang tertulis pada judul teks berikut:

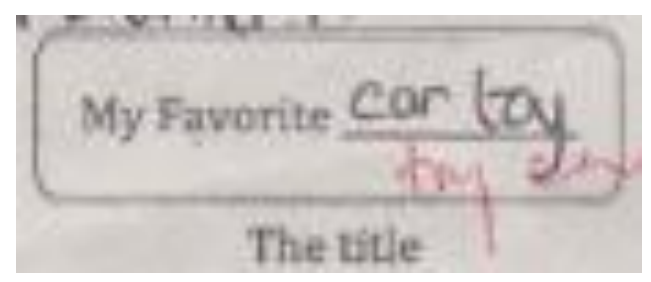

\section{Gambar 6. Cuplikan Penulisan Frase Benda yang Terbalik}

Seharusnya siswa menuliskan 'My Favorite Toy Car', bukan 'My Favorite Car Toy'. Selain itu, siswa ini masih menuliskan judul menggunakan huruf kecil.

Beberapa siswa sudah berhasil mengidentifikasi benda/tempat tertentu dengan benar. Berikut contohnya:

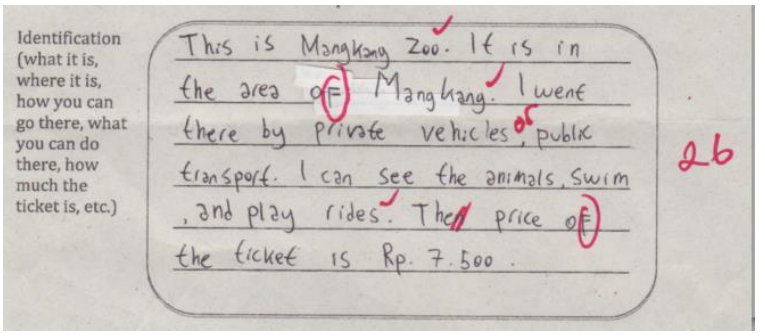

Gambar 7. Cuplikan Identifikasi Tempat Tertentu

Pembelajaran telah direncanakan dengan baik. Guru telah melaksanakan aktivitas pembelajaran sesuai dengan tujuan meskipun kurang bervariasi.

Berdasarkan hasil latihan siswa, observasi, wawancara, dan foto-foto kegiatan, menunjukkan bahwa pembelajaran menggunakan materi otentik berhasil membantu siswa kelas VII/1 SMP Negeri 4 Mataram pada semester 1 tahun pelajaran 2019/2020 meningkatkan kompetensinya dalam menulis teks deskriptif berbahasa Inggris dengan lebih bervariasi.Hal ini sejalandengan hasil penelitian maupundiskusi yang dilakukandan sesuaioleh pendapat Al Azridan Al-Rashdi (2014), Massod (2013), dan Rahman (2013).

Perhatikan grafik berikut:

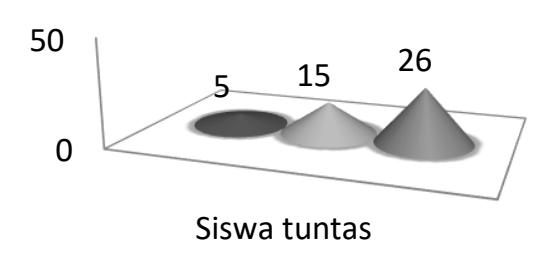

Kondisi awal Setelah tindakan 1

Setelah tindakan 2

Gambar 8. Grafik hasil tindakan 
Dari kondisi awal hanya 5dari 32 siswa $(15,63 \%)$ bisa menulis teks deskriptif berbahasa Inggris dengan bervariasi. Setelah diadakan tindakan siklus pertama dan ke dua, ada peningkatan jumlah siswamasing-masing 15 siswa (46,88\%)dan 26 siswa (81\%).

\section{KESIMPULAN}

Pembelajaran menggunakan media visual otentik dapat meningkatkan kompetensi siswa kelas VII/1 SMP Negeri 4 Mataram pada semester 1 tahun pelajaran 2019/2020 untuk menulis teks deskriptif dengan lebih bervariasi karena bisa meningkatkan motivasi belajar, imajinasi, dan kreasia dan mendapatkan penemuan pengetahuan baru bagi siswa. Media visual otentik yang berbeda antar siswa tidak memungkinkannya untuk menjiplak pekerjaan temannya. Implikasi pedagogis dari penelitian ini adalah siswa akan terhindar dari kebiasaan menjiplak dan menjadi pembelajar dengan tingkat berfikir tinggi sehingga mampu berwacana sosial dengan baik.

\section{DAFTAR PUSTAKA}

Arikunto. (2012). Prosedur Penilaian Suatu Pendekatan Praktek. Jakarta : Rineka Cipta

Azhar. (2003). MediaPembelajaran. Jakarta: RajawaliPers

Daryanto. (2012). Model Inovatif. Yogyakarta: Gava Media

Depdikbud. (2002). Kamus Besar Bahasa Indonesia. Jakarta : PN. Balai Pustaka.

Harmer, Jeremy. (2007). How to Teach. England: Pearson Education Limited.

Huessien, Ashwaq Abd Al-mahde. (2012). Difficulties Faced by Iraqi Teachers of English in UsingAuthentic Materials in the foreign language classrooms. Al- Fatih Journal, 50, 22-39.

Kilickaya, Ferit. (2004). Authentic Materials and Cultural Content in EFL Classrooms. Angkara, Turkey: The Internet TESL Journal, X (7)

Kumalarini, Th. et al. (2008). Bahasa Inggris Sekolah Menengah Pertama Madrasah Tsanawiyah. Jakarta: Pusat Perbukuan.

Masood, Asif. (2013). Exploiting Authentic Materials for Developing Writing Skills at Secondary Level: An Experimental Study. Macrothink Institute: Journal for the Study of English Linguistics. I(1), 21-71

Rahman, Methela. (2013). Using Authentic Materials in the Writing Classes: A Tertiary Level Scenario. Dhaka: Department of English and Humanities (ENH) BRAC University.

Silberman, M. L. (2006). Active Learning : 101 Strategi Pembelajaran Aktif (terjemahan). Bandung: Nuansa

Siregar, Eveline dan Hartini Nara. (2010). Teori Belajar dan Pembelajaran. Jakarta: Ghalia Indonesia

Suryosubroto. (2009). Proses Belajar Mengajar di Sekolah. Jakarta: Rineka Cipta.

Terwilliger, Arin B. (2011). Descriptive Essay Guidelines: Structuring a Descriptive Essay. Writing Handout E-7,1-3

Wikipedia bahasa Indonesia, ensiklopedia bebas.Aktif.id.m.wikipedia.org. 